\title{
Sistema Único de Saúde, 25 anos
}

Em cinco de outubro de 1988, na contramaré do tsunami neoliberal, a Constituição Federal criou o Sistema Único de Saúde (SUS), um bem comum consolidado em cenários de sucessivas crises internas. Aos 25 anos, o jovem SUS instiga dúvidas sobre sua perenidade.

Inquietudes suscitadas pela degradação dos princípios caros à Reforma Sanitária, não anuviam, na leitura de Jairnilson Silva Paim, nesta edição, a premente defesa de um sistema de saúde refundador do pacto social constitucional.

Autores convidados para debater o trabalho de Paim expuseram o paradoxal desafio a ser enfrentado: como apoiar com vigor a concepção de cidadania sobre a qual repousa o sistema público frente às políticas cumulativas de privatização; como encaixar um sistema nacional de saúde universal numa estrutura social que mudou desde a transição democrática, mas que ainda é estratificada e desigual; como persistir na ideia de construção de um estado social redistributivo quando a política é subsumida aos interesses do capital.

O fracasso da toada neoliberal joga luzes sobre o SUS, especialmente para as correntes interpretativas que veem nas atuais políticas de distribuição de renda e nos investimentos em políticas sociais o fulcro de uma nova estratégia de desenvolvimento nacional. A peleja, aqui, será distinguir os processos indutores de mudanças da mera retórica do "transformismo".

A derrocada do SUS não é fato inexorável como a correnteza que a tudo arrasta e leva consigo o leito do seu próprio rio, mas tortuoso será o curso a seguir para conservar do passado os princípios de integralidade com universalidade, e de igualdade com participação.

Veja-se o impasse econômico conjuntural que, para alcançar superávits primários, investir em infraestrutura e abater a dívida pública, impõe a redução das despesas com as políticas sociais. Somam-se a insuficiência e a indefinição de fontes de recursos para a saúde, enquanto o privado fecha o cerco para além do financiamento e da prestação da assistência, pois agora também captura a gestão pública.

Aposta-se no crescimento de um mercado de planos de saúde de olho na massa trabalhadora em ascensão, à cata de mais subsídios públicos, que não entrega o que vende, mas tem presença garantida na condução da regulação.

Assim, segue sem definição clara que modelo e que sistema mobilizarão uma nação que já tem mais de 200 milhões de habitantes e que está sendo convocada a melhorar seus indicadores de saúde, a diminuir adoecimentos e mortes, a incidir sobre determinantes associados aos problemas de saúde prioritários e evitáveis.

Como, então, alcançar um sistema resolutivo, justo e de qualidade? Como reordenar as funções desempenhadas por gestores, profissionais, prestadores e usuários em torno de direitos de cidadania? Como formar, valorizar e fixar trabalhadores da saúde, não só médicos, para que produzam de fato saúde? Espera-se, cada vez mais, a mobilização de aportes teóricos e abordagens metodológicas para responder adequadamente tais questões.

Urge, por fim, uma agenda ampliada: a reforma política democrática que alargue as possibilidades de participação, a reforma tributária socialmente justa, e a rearticulação do SUS com a previdência e a assistência social, conforme previsão do modelo constitucional, incluindo o compartilhamento das atuais e futuras receitas da seguridade social.

Neste momento de intensa expressão pública, que as quimeras que nos assombram cedam lugar ao vislumbre de um sistema de saúde capaz de gerar desenvolvimento, que seja motivo de orgulho e tome lugar de destaque na vida nacional.

Mário Scheffer

Faculdade de Medicina,Universidade de São Paulo, São Paulo, Brasil.

mscheffer@usp.br 